\title{
AN ESTER OF 4-METHOXY CYNNAMIC ACID ISOLATED FROM Xylocarpus moluccencis (Lamk) M. Roem (MELIACEAE)
}

\author{
Tukiran $^{1, *}$, Septiani Setyo Cahyasari ${ }^{1}$, and Kuniyoshi Shimizu ${ }^{2}$ \\ ${ }^{1}$ Department of Chemistry, Faculty of Mathematics and Natural Sciences, State University of Surabaya, \\ Jl. Ketintang, Surabaya, 60231 \\ ${ }^{2}$ Department of Forest and Forest Products Sciences, Faculty of Agriculture, \\ Kyushu University, Fukuoka 812-8581, Japan
}

Received November 2, 2011; Accepted February 19, 2012

\begin{abstract}
An ester derivative of 4-methoxycynnamic acid, i.e. 2-ethylhexyl 4-methoxy cynnamate was isolated for the first time from the chloroform extract of stem bark of Xylocarpus moluccencis (Lamk) M. Roem) (Meliaceae) along with $\beta$-sitosterol and stigmasterol. The first structure was elucidated with the help of various spectroscopic techniques, including IR, GC-MS, and NMR spectra. Two last structures were determined by comparison with the reported compounds in literature. These compounds were also found in the hexane extract of the plant.
\end{abstract}

Keywords: Ester of 4-methoxycynnamic acid; $\beta$-sitosterol; stigmasterol; Xylocarpus moluccencis

\section{ABSTRAK}

Suatu turunan ester dari asam 4-metoksisinamat, yaitu 2-etilheksil 4-metoksisinamat telah berhasil diisolasi untuk pertama kalinya dari ekstrak kloroform kulit batang tumbuhan Xylocarpus moluccencis (Lamk) M. Roem) (Meliaceae) bersama dengan $\beta$-sitosterol dan stigmasterol. Struktur senyawa pertama telah dielusidasi dengan bantuan berbagai teknik spektroskopi mencakup spektrum IR, GC-MS, dan NMR. Struktur dua senyawa berikutnya telah ditentukan melalui perbandingan dengan senyawa yang telah dilaporkan dalam literatur. Dua senyawa ini telah pula ditemukan pada ekstrak heksana dari tumbuhan tersebut.

Kata Kunci: Ester 4-metoksisinamat; $\beta$-sitosterol; stigmasterol; Xylocarpus moluccencis

\section{INTRODUCTION}

Meliaceae contains various types of compounds, especially pentacyclic triterpenoid and limonoids [1]. As known that Xylocarpus genus belongs to the family Meliaceae, therefore the plant can be predicted consisting of the compounds. The plants belonging to Xylocarpus genus are composed of 3 species, i.e., $X$. granatum, $X$. moluccensis and $X$. rumphii. According to information from NAPRALERT database developed by University of Illinois at Chicago, several types of compounds present in plants of Xylocarpus genus can be classified into groups as follows: carbohydrates, glyceride ester, isoquinoline alkaloids, quinolone alkaloids, phenolic compounds, secoiridoid monoterpenes, steroids, and triterpenes.

Literature research on chemical constituents consisted of $X$. moluccensis reported that the species contain type of monoterpenoid and limonoid compounds, with marker compound, i.e. Xylomollin and Xyloccensin 1,2 [2]. Continues phytochemical research on the wood of the plant have obtained three new limonoids, i.e. xyloccensins G, H, and I [3]. Two new limonoids, namely xyloccensin $\mathrm{I}$ and xyloccensin $\mathrm{J}$, have also been isolated from the plant and $X$. granatum [4-5].

Past our investigations on the chemical constitutes of the stem bark of mangrove plant, $X$. moluccensis (Lamk) M. Roem), one of Meliaceous plants, have yielded two steroidal compounds, i.e. stigmasterol (2) and $\beta$-sitosterol (3) from hexane extract [6]. As part of our continuing search for bioactive insecticidal natural products from mangrove plants [7], we now just describe the isolation and structural elucidation of an ester derivative of cynnamic acid, named 2-ethylhexyl 4-methoxycynnamate (1) belonging to be a phenolic compounds from chloroform extract of $X$. moluccensis.

\section{EXPERIMENTAL SECTION}

\section{Materials}

Powdered and dried samples used in this research is $X$. moluccencis, especially stem bark was

* Corresponding author. Tel/Fax : +62-31-8298761/8298761

Email address : btukiran@yahoo.com

Tukiran et al. 


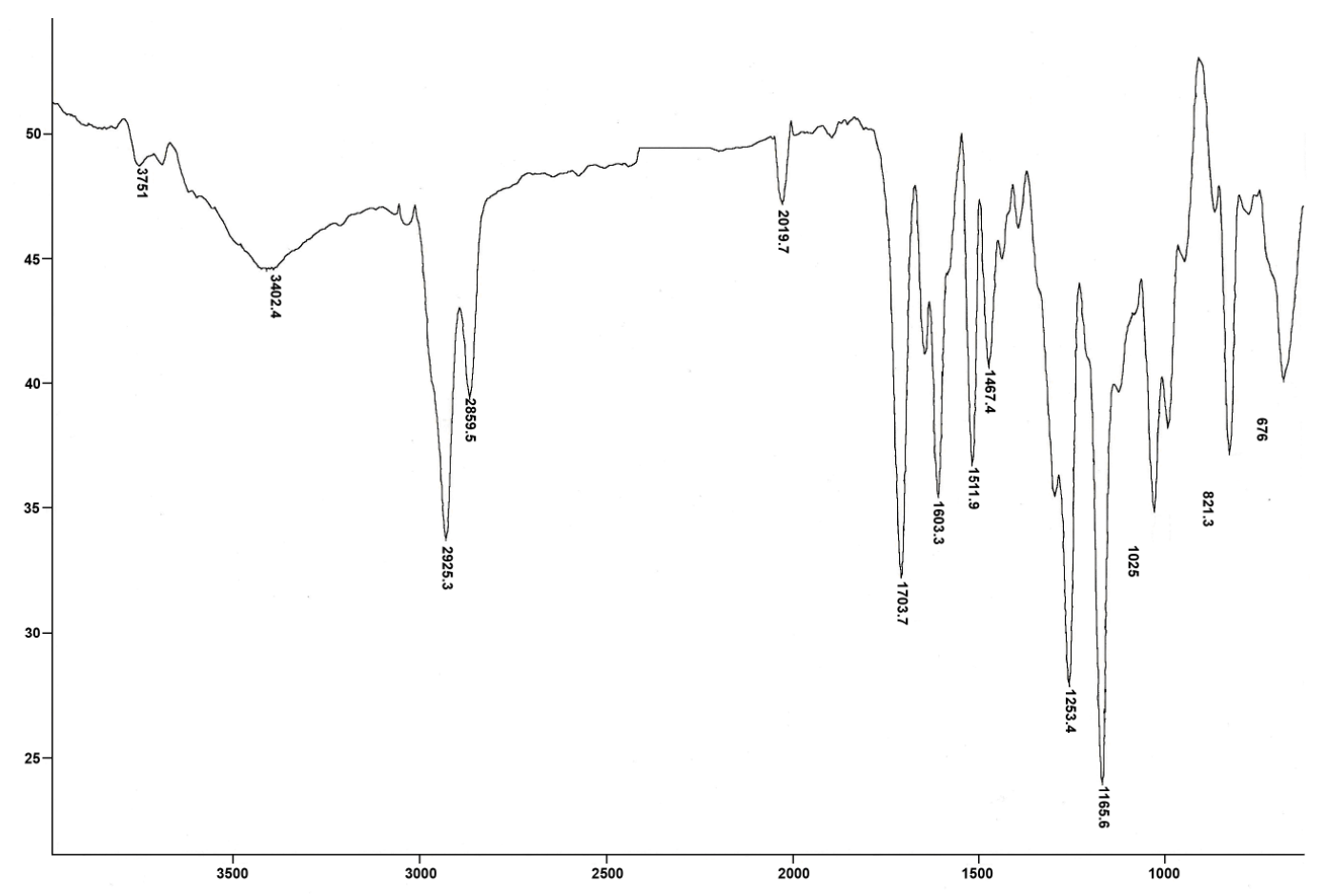

Fig 1. IR Spectrum of Compound 1

collected in March, 2009 from Kebun Raya Purwodadi, Pasuruan. The plant was identified by Herbarium LIPI Staff, Purwodadi, and its specimen was deposited in the Herbarium. Materials are used for vacuum liquid chromatography (VLC) using Si Gel Merck 60 GF $_{254}$, gravitational column chromatography (GCC) using $\mathrm{Si}$ Gel Merck 60 (60-70 mesh), always monitored by thin layer chromatography (TLC) using plate of Si Gel Merck Kieselgel $60 \mathrm{~F}_{254}, 0.25 \mathrm{~mm}(20 \times 20 \mathrm{~cm})$. Organic solvents used in the research might be pro analysis (p.a.) and distillated, i.e., methanol, chloroform, hexane, and ethyl acetate. The spray reagents used for TLC was $1 \% \mathrm{FeCl}_{3}$ solution for phenolic compounds and Liebermann-Burchard for triterpenes and steroids.

\section{Instrumentation}

Isolated compound (1) was measured by using IR spectrophotometers with Buck Scientific M500. ${ }^{1} \mathrm{H}$ - and ${ }^{13} \mathrm{C}-\mathrm{NMR}$ using spectrometer of JEOL JNMAL300/AL400 FTNMR, operated at $399.65 \mathrm{MHz}\left({ }^{1} \mathrm{H}\right)$ and 100.40 $\mathrm{MHz}\left({ }^{13} \mathrm{C}\right)$, with tetramethylsilane as internal standard, and spectrometer of GC-MS Shimadzu QP2010S. Melting point of compound 1 was determined on Electrothermal Apparatus.

\section{Procedure}

The milled and dried stem bark $(3 \mathrm{~kg})$ of $X$. moluccencis was extracted with chloroform (10 L) for
$24 \mathrm{~h}$ and the process was repeated three times. The chloroform extract, on removal of the solvent under reduced pressure by evaporation, gave a brown residue $(15 \mathrm{~g})$. A portion $(7.5 \mathrm{~g})$ of the total chloroform extract were subjected by VLC using hexane-ethyl acetate system (100:0 0:100) followed by methanol to yield 14 fractions. This chromatographic step was repeated twice on portions of $7.5 \mathrm{~g}$ each of the chloroform extract. Five primary fractions were ultimately obtained on combining the eluates on the basis of TLC. The second fraction $(2.3 \mathrm{~g})$ was again fractionated by GCC using hexane : ethyl acetate $(96: 4)$ to yield 57 fractions. Furthermore, the fractions can be grouped on the basis of TLC to give 6 fractions, i.e., fraction $A(1-9), B(10), \quad C(11-25)$, D (26), $E(27-35)$, and $F(36-57)$. Fraction $A(1-9)$ is allowed in open room to give yellowish residue. Next, the residue is crystallized from hot methanol to yield a white crystal as compound 2 and 3 to be a mixture (30 mg). When performed by Liebermann-Burchard reagent, the mixture gave blue color indicating the presence of steroidal compounds. Then, the fraction $D$ (26) was evaporated occurred a white precipitate. The precipitate was, then purified by recrystallization using hexane to afford compound 1 as needle white crystal (pure enough) $(10 \mathrm{mg})$. The purity of the compound 1 can also be shown by GC-MS chromatogram (see Fig. 3). When tested by $\mathrm{FeCl}_{3} 1 \%$ (in methanol), it showed pale yellow color indicating the presence of phenolic compound. 


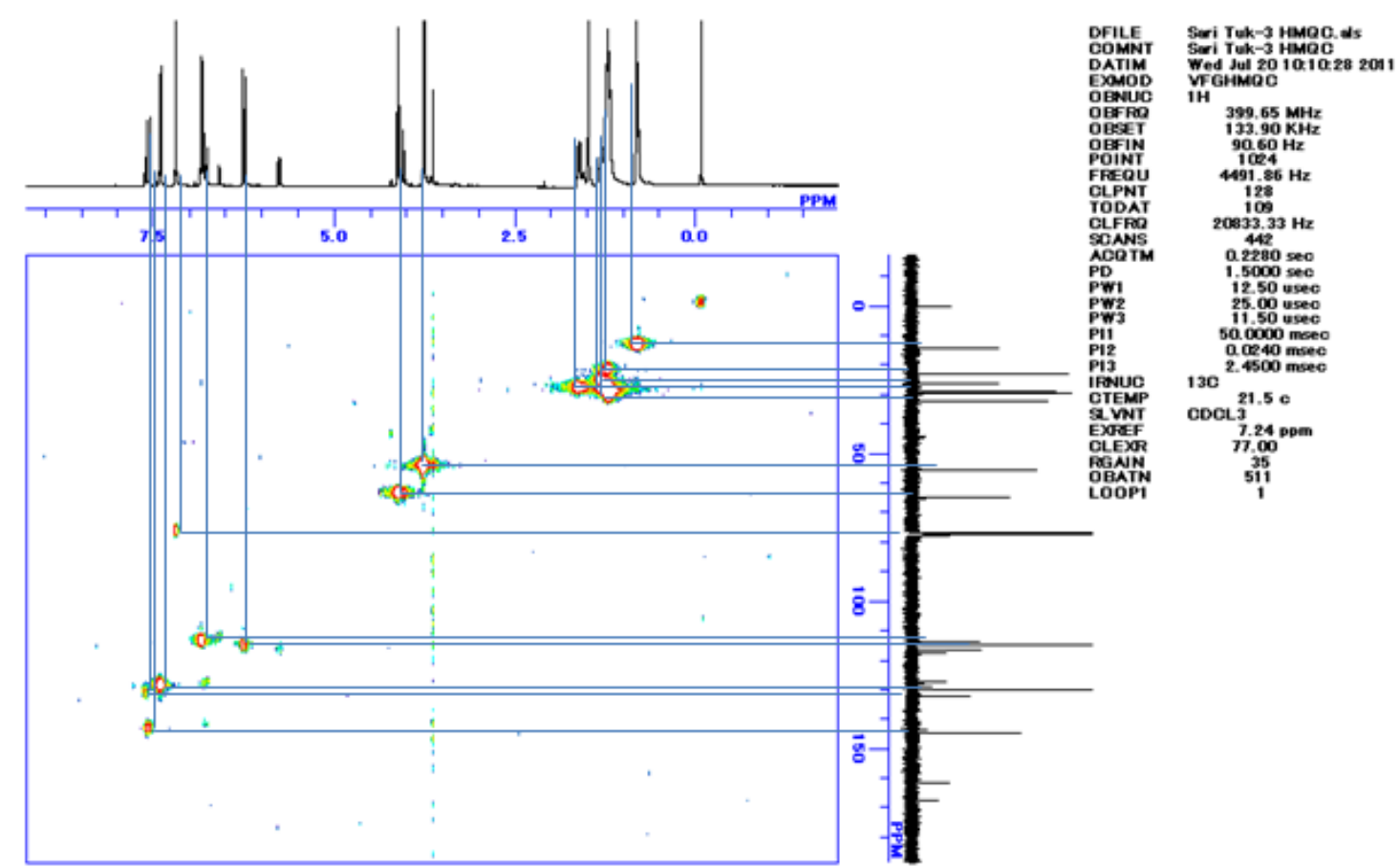

Fig 2. HMQC Spectrum of Compound 1

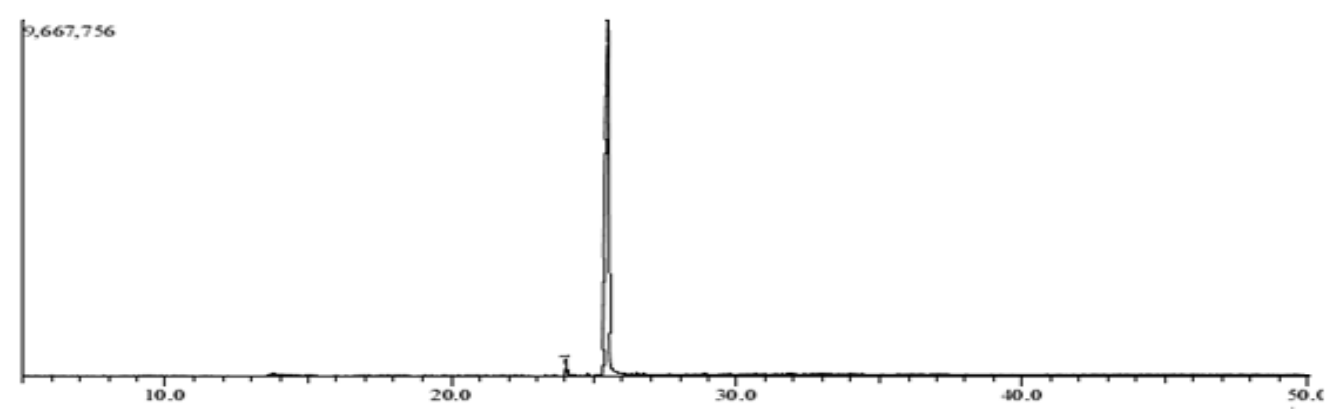

Fig 3. GC-MS Chromatogram of Compound 1

Table 1. ${ }^{1} \mathrm{H}$ and ${ }^{13} \mathrm{C}$ NMR data of compound 1

\begin{tabular}{llr}
\hline \multirow{2}{*}{ No } & \multicolumn{2}{c}{ Compound 1 } \\
\cline { 2 - 3 } & $\delta_{\mathrm{H}}$ (multiplicity, J in $\left.\mathrm{Hz}\right)$ & \multicolumn{1}{c}{$\delta \mathrm{c}$} \\
\hline 1 & - & 167.4 \\
2 & $6.36(\mathrm{~d}, 16.0)$ & 115.8 \\
3 & $7.64(\mathrm{~d}, 16.0)$ & 144.2 \\
& & \\
$1^{\prime}$ & - & 132.1 \\
$2^{\prime}\left(6^{\prime}\right)$ & $7.48(\mathrm{~d}, 8.4)$ & 129.7 \\
$\left.3^{\prime} 5^{\prime}\right)$ & $6.90(\mathrm{~d}, 8.4)$ & 114.3 \\
$4^{\prime}$ & - & 161.3 \\
$-\mathrm{OMe}$ & $3.84(\mathrm{~s})$ & 55.4 \\
& & \\
$1^{\prime \prime}$ & $4.18(\mathrm{t})$ & 64.6 \\
$2^{\prime \prime}$ & $1.31(\mathrm{~m})$ & 31.8 \\
$3^{\prime \prime}$ & $1.69(\mathrm{~m})$ & 29.2 \\
$4^{\prime \prime}$ & $1.56(\mathrm{~m})$ & 28.8 \\
$5^{\prime \prime}$ & $1.28(\mathrm{~m})$ & 22.6 \\
$6^{\prime \prime}$ & $0.88(\mathrm{t})$ & 14.1 \\
$7^{\prime \prime}$ & $1.25(\mathrm{~m})$ & 26.0 \\
$8^{\prime \prime}$ & $0.88(\mathrm{t})$ & 14.1 \\
\hline
\end{tabular}

\section{RESULT AND DISCUSSION}

\section{2-Ethylhexyl 4-methoxycynnamate (1)}

Needle white crystalline form, m.p. $35-36{ }^{\circ} \mathrm{C}$. - IR $(\mathrm{KBr}) \cup\left(\mathrm{cm}^{-1}\right)=2925.3,2859.5,1703.7,1603.3$, 1511.9, 1467.4, 1253.4, 1165.6, and $821.3 \mathrm{~cm}^{-1}$ (see Fig. 1). ${ }^{1} \mathrm{H}$ - and ${ }^{13} \mathrm{C}$-NMR (chloroform-deuterium): See Table 1. -GC-MS, m/z: $290\left(\mathrm{C}_{18} \mathrm{H}_{26} \mathrm{O}_{3}\right)$ (see Fig. 4).

Compound 1 was obtained as needle white crystalline form, m.p. $35-36{ }^{\circ} \mathrm{C}$. Its molecular formula was established as $\mathrm{C}_{18} \mathrm{H}_{26} \mathrm{O}_{3}$ in which Double Bond Equivalence (DBE) is five (5) consisting of 1 benzene ring and 1 unsaturated carbon-carbon unit. The IR indicated the presence of aliphatic (2925.3 and $\left.2859.5 \mathrm{~cm}^{-1}\right)$, ester carbonyl group $\left(1703.7 \mathrm{~cm}^{-1}\right)$, aromatic (1603.3, 1511.9, and $\left.1467.4 \mathrm{~cm}^{-1}\right)$, oxygenated benzene $\left(1253.4 \mathrm{~cm}^{-1}\right)$, alkyl ester $(1165.6$ $\left(\mathrm{cm}^{-1}\right)$, and 1,4-disubstituted benzene $\left(821.3 \mathrm{~cm}^{-1}\right)$ 


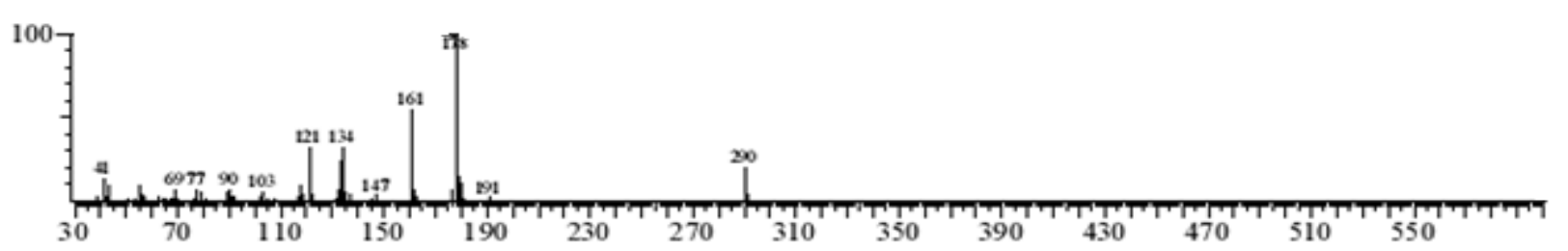

Fig 4. GC-MS Spectrum of Compound 1

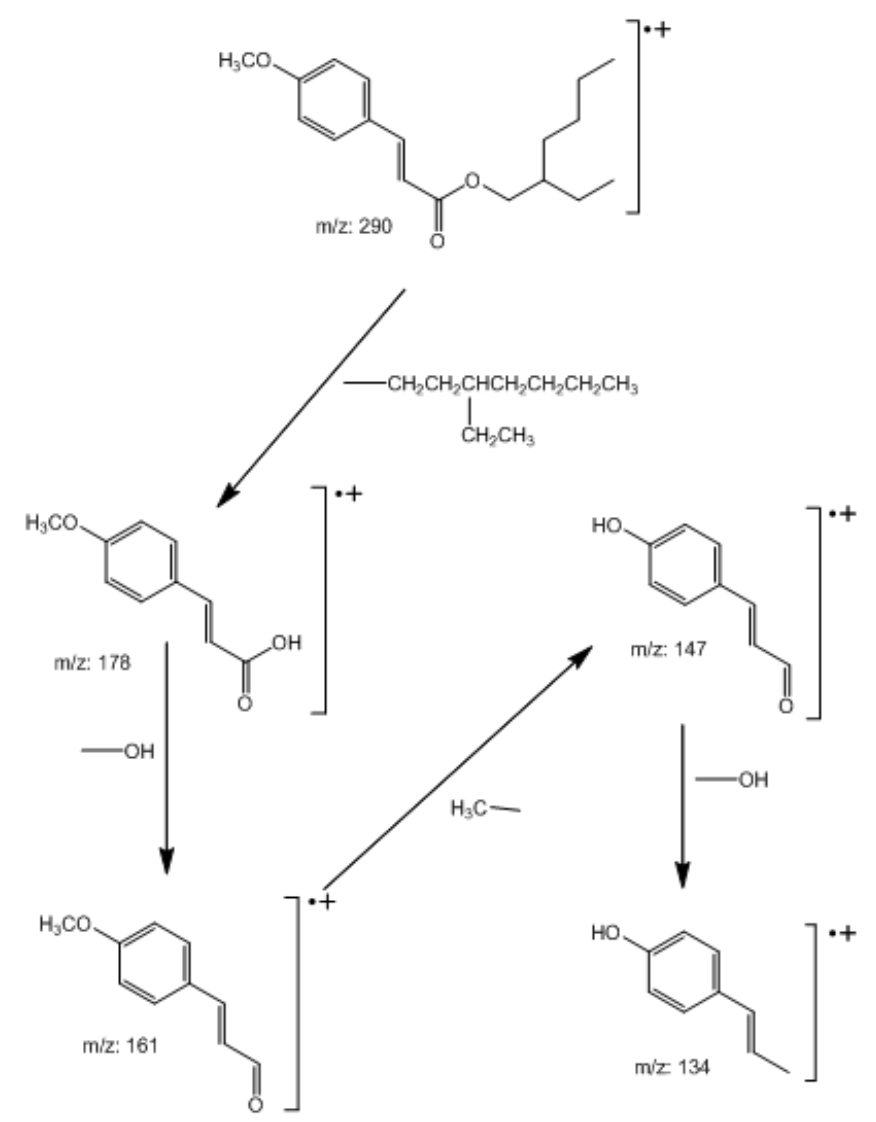

Fig 5. Fragmentation Pattern of Compound 1

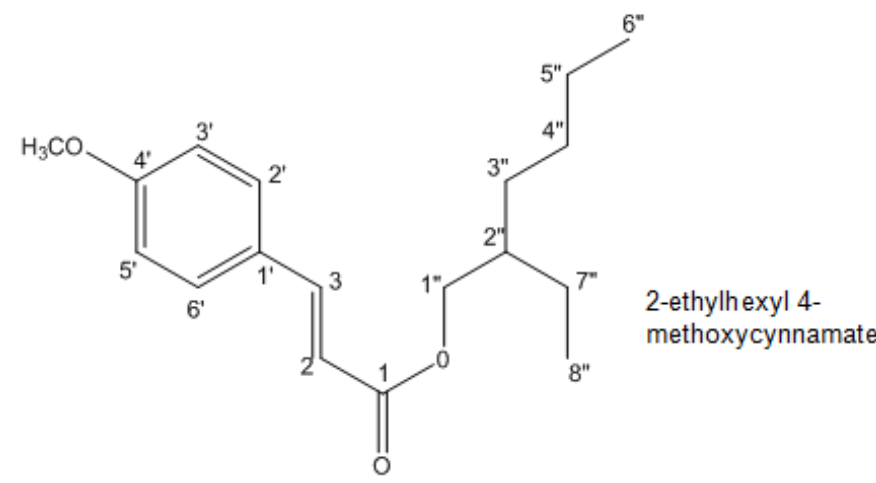

functionalities (see Fig. 1). The evidence of the data is supported by GC-MS (m/z: 290) $\left(\mathrm{C}_{18} \mathrm{H}_{26} \mathrm{O}_{3}\right)$ (see Fig. 4) and NMR data (see Table 1).

The analysis of its NMR data, including NMR one dimension ( ${ }^{1} \mathrm{H}$ - and $\left.{ }^{13} \mathrm{C}-\mathrm{NMR}\right)$ and two dimension (HMQC spectrum only), allowed for an unambiguous assignment of proton and carbon signals (see Table 1). The ${ }^{1} \mathrm{H}-\mathrm{NMR}$ spectrum of 1 displayed two sets of orthocoupled aromatic proton signals in $\mathrm{A}_{2} \mathrm{X}_{2}$ spin system for the presence of one -methoxyphenyl group at $\delta 6.90$ $\left[2 \mathrm{H}, \mathrm{d}, J=8.4 \mathrm{~Hz}, \mathrm{H}-3^{\prime}\left(5^{\prime}\right)\right], 7.48 \mathrm{~d}[2 \mathrm{H}, \mathrm{d}, J=8.4 \mathrm{~Hz}$, $\left.\mathrm{H}-2^{\prime}\left(6^{\prime}\right)\right]$. The ${ }^{1} \mathrm{H}-\mathrm{NMR}$ spectrum of 1 also indicated the presence of a set of trans configuration at $\delta 6.36(1 \mathrm{H}$, $\mathrm{d}, J=16.0 \mathrm{~Hz}, \mathrm{H}-2)$ and $7.64(\mathrm{~d}, J=16.0 \mathrm{~Hz}, \mathrm{H}-3)$.

The ${ }^{13} \mathrm{C}-\mathrm{NMR}$ spectrum of $\mathbf{1}$ displayed the presence thirty four signals representing significant eighteen carbons, consisting of $9 \mathrm{sp}^{3}$ carbon signals at

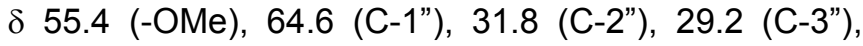
28.8 (C-4"), 26.0 (C-7"), 22.6 (C-5"), and 14.1 (C-6"/8") ppm, and $9 \mathrm{sp}^{2}$ carbon, including one $\alpha, \beta$-unsaturated carbonyl at $\delta 167.4(\mathrm{C}=\mathrm{O}), 144.2$ and $115.8(\mathrm{C}=\mathrm{C})$ and one oxyaryl carbon at $\delta 161.3$ (C-4'), 132.1 (C-1'), 129.7 (C-2'/6'), and 114.3 (C-3'/5'). These spectral data indicated that 1 is an ester of 1,4-disubstutited cynnamic acid as part of the structure attached an alkyl. The complete assignment of the protonated carbon was confirmed by means of HMQC spectrum (Fig. 2). The NMR data were consistent with 2 Ethylhexyl 4-methoxycynnamate. The proposed compound 1 is supported by small detail data of GCMS fragmentation as presented in Fig. 5.

\section{CONCLUSION}

An ester derivative of 4-methoxy cynnamic acid, namely 2-ethylhexyl 4-methoxycynnamate was isolated from chloroform extract of Xylocarpus moluccencis (Lamk) M. Roem (Meliaceae) along with stigmasterol and $\beta$-sitosterol. This is the first report of the chemical constituents of this species, and the type of compound isolated was in accordance with the established information of Xylocarpus genus.

\section{ACKNOWLEDGEMENT}

We would like to our deep thanks to the Herbarium LIPI Staff, Purwodadi, Indonesia for identification of the plant. We also thank to the Department of Chemistry, Faculty of Mathematics and Natural Sciences, Universitas Gadjah Mada in Yogyakarta for measuring mass spectra (GC-MS). 


\section{REFERENCES}

1. Shahid-Ud-Daula, A.F.M., and Basher, M.A., 2009, Malaysian J. Pharm. Sci., 7, 1, 9-21.

2. Ramanathan, G., Kathiresan, K., and Ravikumar, S., 2004, Seshaiyana, 12, 2, 7-8.

3. Taylor, D.A.H. 1983, Phytochemistry, 22, 5, 12971299.

4. Alvi, K.A., Crews, P., Aalbersberg, B., and Prasad, R., 1991, Tetrahedron, 47, 43, 8943-8948.

5. Wu, J., Xiao, Q., Zhang, S., Li, X., Xiao, Z., Ding, H., and Li, Q., 2005, Tetrahedron, 61, 35, 8382-8389.
6. Taufiqurrohman, M., and Tukiran, 2010, Bioinsecticidal Test of Isolated Compound from The Stem Bark of Nyiri Batu (Xylocarpus moluccensis (Lamk) M. Roem) (Meliaceae), Science National Seminar, Science Education, Postgraduate Program, State University of Surabaya, 16 January 2010.

7. Nurdiana, R., Septiani, S.C., and Tukiran, 2011, The Potency of Nyiri Batu (Xylocarpus Moluccensis (Lamk) M. Roem) (Meliaceae) As Bioinsectisidal Materials, Chemistry National Seminar, Universitas Sebelas Maret Surakarta (UNS), 8 October 2011. 